\title{
The Wearing of Significative Badges, Religious and Secular: The Social Meaning of a Behavioural Pattern
}

\author{
Jos KolDEWEIJ
}

A n important aspect of visual culture in the late Middle Ages was the ornament or enseigne invested with a certain meaning. ' People in all walks of life sported badges, brooches and pendants. Whether cheap baubles or costly items of jewellery, they all possessed added value in the eyes of those who wore and beheld them. Then as now, status played an important role: such ornaments reflected the wearer's prosperity.

However, the meaning - overt or implicit — of ornaments, and thus of wearing them, was on a different level, and this implies the basic incorrectness of the term. The primary function of the 'ornament' was not ornamental, but apotropaic: it was supposed to avert evil and bring luck. In other words, these were amulets in the broadest sense, and they sometimes reflected very different aspects. For medieval man there was no essential difference between the primary function of religious and secular badges, nor between Christian and non-Christian ones. The 'language' of what we tend to see as erotic representations, and of the more anecdotal or secular symbolic representations, differed from that of religious depictions Christian symbolism, saints and/or their attributes - but the ultimate

\footnotetext{
"Translated from Dutch by Ruth Koenig.

'A comprehensive survey of this material, with extensive bibliographic references: H.J.E. van Beuningen \& A.M. Koldeweij (eds.), Heilig en profaan. 1000 laat-middeleeuwse insignes uit de collectie H.J.E. van Beuningen, Rotterdam Papers 8 (Cothen 1993).
} 


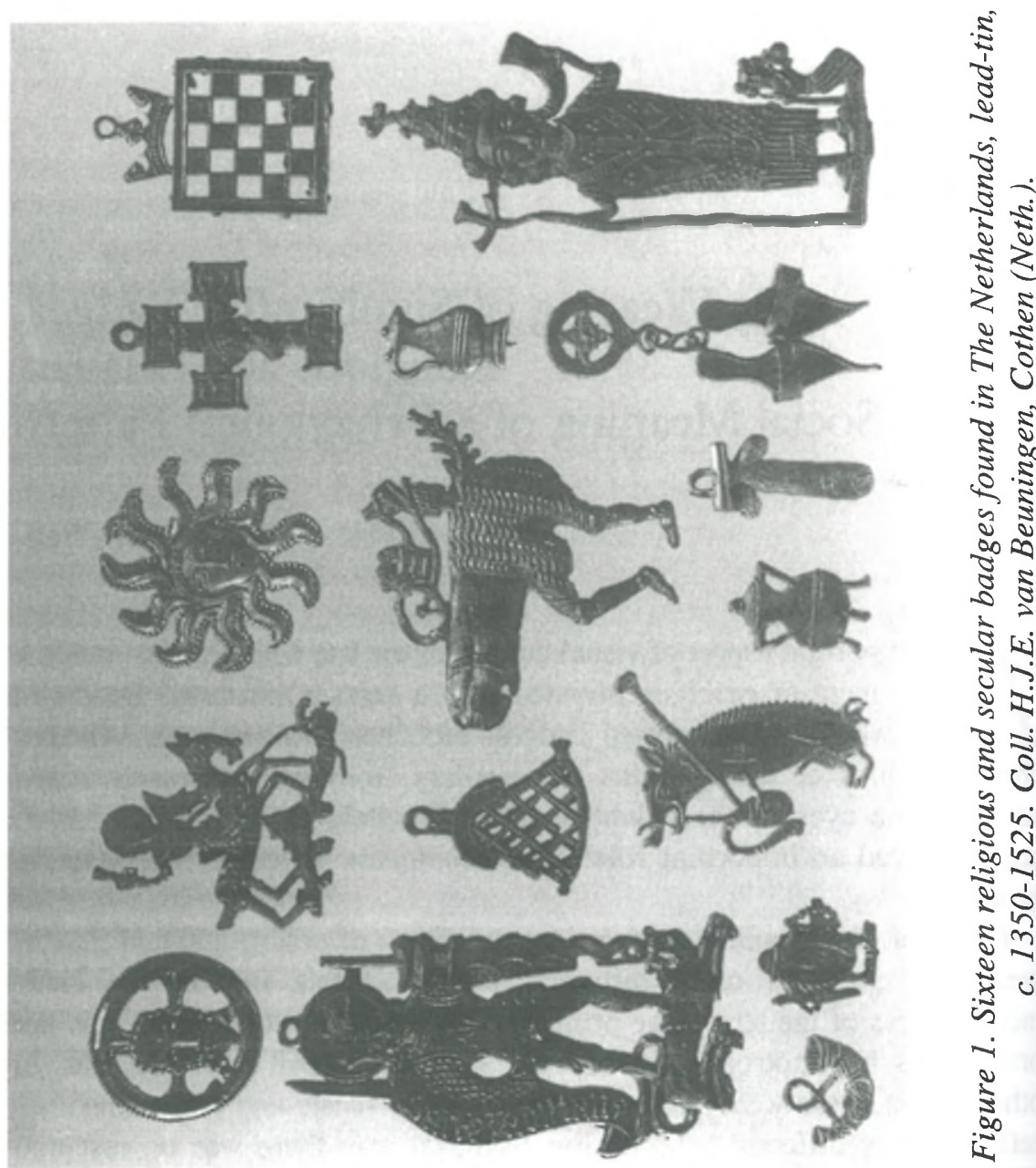




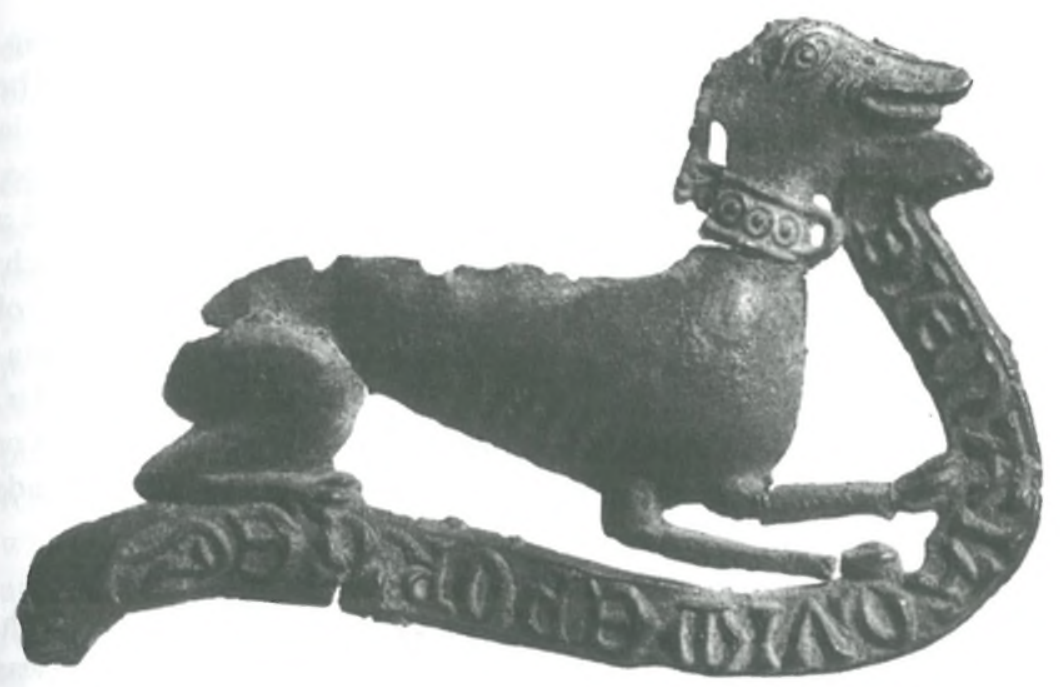

Figure 2. Badge in the form of a dog, lead-tin, $34 \times 55 \mathrm{~mm}$, France fourteenth century. Cologne, Kunstgewerbemuseum der Stadt Köln, inv. no. $J 405$

meaning and assigned value did not (Fig. 1). ${ }^{2}$

'Bien ait qui ma fet, qui me vent et qui me porte, Marye' ('Well-being to him who made me, who sells me and who wears me, Mary'), reads the inscription on a fourteenth-century pewter brooch with a representation of the Virgin which was found in the nineteenth century in the Seine at Paris, as Victor Gay reported in his famous Glossaire. ${ }^{3}$ The inscription on this

${ }^{2}$ This proposition was recently elaborated by Jan Baptist Bedaux: J.B. Bedaux, 'Laatmiddeleeuwse sexuele amuletten. Een sociobiologische benadering', in: J.B. Bedaux \& A.M. Koldeweij (eds.), Annus Quadriga Mundi. Opstellen over middeleeuwse kunst opgedragen aan Prof. Dr. Anna Esmeijer, Clavis, Kunsthistorische Monografieën 8 (Utrecht/Zutphen 1989) 16-30; J.B. Bedaux, 'Funktie en betekenis van randdecoratie in middeleeuwse handschriften', Kunstlicht 14 (1993) 28-33; J.B. Bedaux, 'Profane en sacrale amuletten', in: A.M. Koldeweij \& A. Willemsen (eds.), Heilig en Profaan. Laatmiddeleeuwse insignes in cultuurhistorisch perspectief (Amsterdam 1995) 26-35.

${ }^{3}$ Victor Gay, Glossaire archéologique du Moyen Age et de la Renaissance, I (Paris 1887) 634, illustrated. At that time the brooch was in the Musée de Cluny, Paris, where it still is: Denis Bruna, Enseignes de pèlerinage et enseignes profanes. Musée National du Moyen Age - Thermes de Cluny. Catalogue (Paris 1996), 105-6, no. 117. Gay made a mistake in the text; the last words are AVE.MARIA. Denis Bruna publishes an almost identical and extremely well-preserved insigne, kept in the Musée Boucher de Perthes, Abbeville. 
religious brooch refers unequivocally to the meaning imputed to the cheap, mass-produced trinket as an averter of evil and a good-luck charm. The banderole text on a similar, but secular, popular ornament, also made in France but its find-spot unknown, clearly implies that this category, too, was thought to possess the same magical properties. It is in the form of a dog wearing a collar and acting as a guard to the wearer of the brooch: 'Bien aia qui me porte' (Fig. 2). ${ }^{4}$ Among the belongings of Charles V of France, inventoried in 1380, were three valuable brooches. The representations are not specified and so could have been either religious or secular, but their 'magical' significance is stated explicitly: 'Troys enseignes d'or qui ont esté faictes pour le mal des rains' ('Three golden badges made against kidney complaints'). ${ }^{5}$

A remarkable fact, and one which has only recently emerged from research, is that in the period from the late twelfth century into the fifteenth there was an enormous variety of mass-produced, very cheap 'jewellery' ranging from Christian enseignes, i.e. pilgrims' badges and other devotionalia, to the secular brooches and charms, which may be considered equally important because of their conspicuous character. In the late fourteenth and early fifteenth centuries the picture changed drastically, and in the latter half of the fifteenth century and the first half of the sixteenth, predominantly Christian enseignes rub shoulders with apparently abstract, decorative badges and figurative items such as coin brooches.

Two examples of secular enseignes discussed below belong to the small group of 'classical' themes (Figs. 7 and 8); for whom such cheap brooches were made, who wore such representations, and why, are intriguing questions. In both cases the elitist and fairly intellectual subject matter seems to be inconsistent with the character of the mass-produced popular ornament: 'Aristotle and Phyllis' and a 'Wheel of Fortune'. In other words, these simple brooches indicate that ordinary folk were familiar with the depicted themes, themes which may even have been popular; why else would such trivial trinkets have been made in the first place? The first questions prompted by this observation are of course what made them popular, where and when the brooches were sold and whether it is possible to define the buyers and/or wearers in more detail. I see an obvious pointer,

\footnotetext{
${ }^{4}$ Hanns-Ulrich Haedeke, Zinn, Kataloge des Kunstgewerbemuseums Köln 3 (Cologne 1976) 73 no. 66. This insigne was published in 1887 by Victor Gay, in whose collection it was at the time. Gay, Glossaire, I 152.

${ }^{5}$ Léon de Laborde, Glossaire Français du moyen age (Paris 1872) 262.
} 
unfortunately unsubstantiated by concrete examples as yet, in medieval drama and itinerant minstrels, story-tellers and puppeteers. ${ }^{6}$ After all, was not the situation similar for both secular and religious badges? On the one hand there was the market where material of a more general nature, bound neither to place nor occasion, was sold. On the other hand specific merchandise was peddled for special events: a spectacle at a place of pilgrimage, a journey to a saint's or martyr's shrine, or a reliquary procession, stimulated the same interest in thematically relevant badges as did secular events. Visitors to Ninove and Geraardsbergen, two Flemish places of pilgrimage which were not all that far apart, bought badges representing Cornelius or Adrian, the saints they had venerated and in whose honour processions and fairs were held, reliquaries were displayed and so forth. ${ }^{7}$ After seeing performances of the miracle play Mariken van Nieumeghen, or after reading or listening to the tale, the surviving version of which was written between 1485 and $1510,{ }^{8}$ people will have eagerly snapped up brooches in the form of an $\mathrm{M}$, which were, incidentally, in circulation much earlier (Fig. 3). ${ }^{9}$

In the miracle play the traditional abbreviation of $\mathrm{M}$ for Mary gives rise to a sly play on words (or letters). At the beginning of the story Mariken decides to follow the devil, Moenen, who thereupon makes one more urgent request: ${ }^{10}$

${ }^{6}$ For an idea of early theatrical practice see: H. van Dijk, '14 mei 1363: De graaf van Blois bezoekt een zoldertheater in Dordrecht - Middelnederlands toneel', in: M.A. Schenkeveld-van der Dussen (ed.), Nederlandse Literatuur, een geschiedenis (Groningen 1993) 62-7.

${ }^{7}$ Figure 1, bottom right: from Ninove, Pope Cornelius with a horn, a crozier and a kneeling pilgrim; on the left: from Geraardsbergen, Saint Adrian as a knight, with an anvil and a hammer, trampling on a lion.

${ }^{8}$ W.H. Beuken (ed.), Die waerachtige ende een seer wonderlijcke historie van Mariken van Nieumeghen, Klassiek Letterkundig Pantheon 170 (Zutphen 1972, third, completely revised edition); Therese Decker \& Martin W. Walsh (eds.), Mariken van Nieumeghen. A Bilingual Edition, Studies in German Literature, Linguistics and Culture; Medieval Texts and Translations (Columbia 1994).

${ }^{9}$ Van Beuningen \& Koldeweij, Heilig en Profaan, 310-14, figs. 966-78 (M badges). See figure 3, top middle: a crowned $\mathrm{M}$; bottom middle: a crowned $\mathrm{M}$ with the inscription AMOURS and a loving couple; bottom right: an $\mathrm{M}$ in a floral border; top left: the monogram MRI (Maria?) on a chain.

${ }^{10}$ Text and transl. from Decker \& Walsh, Mariken van Nieumeghen, 50-5. The numbering of the lines conforms with Beuken, Mariken van Nieumeghen. 


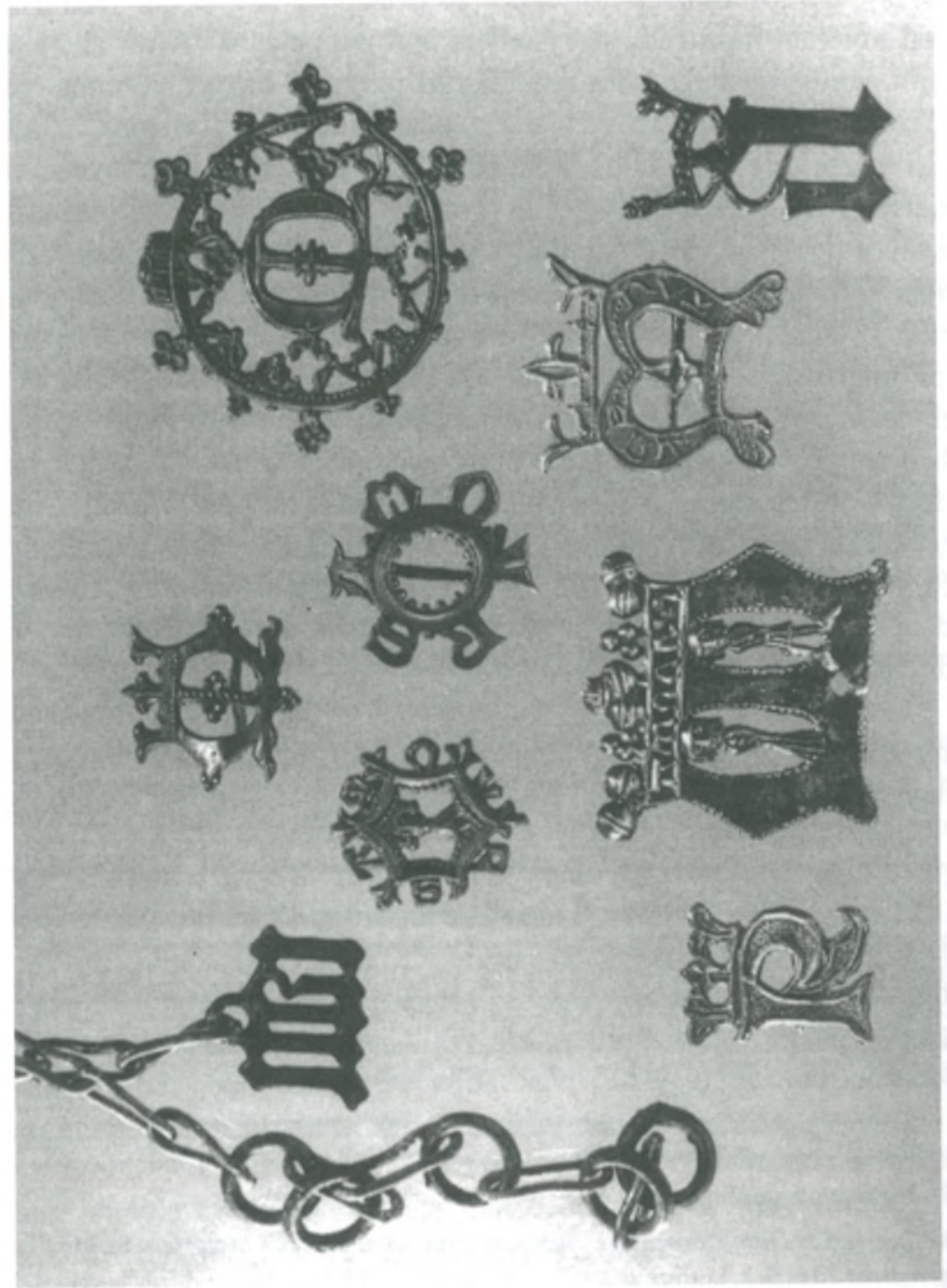

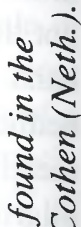

5

$\pm 2$

2.5

2.

కก

จ

궁

का स्र

ป

$8 x$

ठे

พิن

₹ ต

อิ

\&

$\equiv m$

ปे

$\rightarrow$

รี.

( )

$\stackrel{5}{3}$

$z$

ले है

० ह

I

$\rightarrow$

i $\frac{5}{2}$ 
That you give up your name and from now on call yourself something else. "Mary" is an unpleasant name for me. My companions and I have already had a lot of trouble with one Mary; we'll never have much appreciation for that name (vv. 272-6).

Mariken is unwilling to comply with Moenen's wish:

After all, it is the sweetest, most noble name in the whole world, and everyone finds it delightful. Mary or Maria. How did you know my name? By all that lives, I don't want to be called anything else. I don't think there is a sweeter name (vv. 281-4).

Moenen fears that his evil plans will come to nought, but after some discussion the two come to terms. The devil makes a wily proposal:

All right, since you are so fond of that name, listen, I'll compromise. I'll be satisfied if you only use the first letter of your name, my exquisite, gentle lady! That's the letter " $M$ "; that's why you'll be called Emily! After all, there are many girls and women in your country called Emily (vv. 306-10).

So Mariken reluctantly agrees:

I'll be satisfied with the first letter. From now on I shall be known everywhere as Emily (vv. 313-14).

Badges with an M, crowned or not, are wonderfully appropriate references to the miracle play, certainly when they are embellished with a male and female figure or the word AMOURS. M stands not only for minne (love) but also for Emily and Mary; love is the principal theme of the story: earthly, physical love in Moenen's case and spiritual love, ultimately triumphant, in Maria's. A badge in the form of a crowned $M$ epitomizes the miracle in referring to provocative, sensual attraction but at the same time transcending it, for virtue prevails. Surely people fired with enthusiasm about the story they had heard or the play they had seen would be eager to wear such a badge. Moreover, the letter $\mathbf{M}$ in Mariken van Nieumeghen, as a reference to the Mother of God, admirably performs the apotropaic function assigned to charms: in spite of everything the Virgin Mary protected her namesake because the worldly, sinful creature did not renounce her devotion; Mariken continued to bear her name, albeit not as a badge. ${ }^{11}$

\footnotetext{
"It is this aspect of the name Emily that Decker and Walsh emphasize in the introduction to the English translation of their book. Decker \& Walsh, Mariken van Nieumeghen, 6-12.
} 

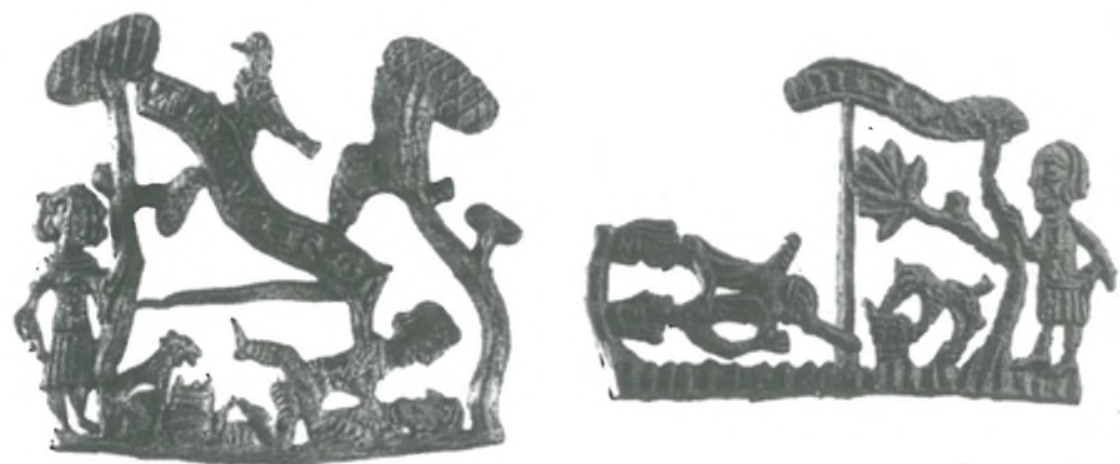

Figures 4 \& 5. Two badges representing the Chatelaine of Vergi and her lover, observed by her kinsman the lord. Found in Dordrecht and Nieuwlande (Neth.), lead-tin, $44 \times 50$ and $33 \times 55 \mathrm{~mm}$, c. 1375-1425. Coll. H.J.E. van Beuningen, Cothen (Neth.)

And might there not be a similar story behind the Chatelaine of Vergi brooch? Two fairly well-preserved examples and one large, slightly different fragment of this simple, highly anecdotal piece are currently known (Figs. 4 and 5). They show the crucial episode of the story: the lord observing the Chatelaine and her lover after the lady's lapdog has signalled that the coast is clear. ${ }^{12}$ These pewter brooches must have been cheap in view of the technique, slipshod workmanship and material, and were probably produced in large quantities. Additional confirmation is supplied by the fact that the two complete discovered brooches are each other's mirror image: evidently new dies were cut from the actual brooches. The

\footnotetext{
${ }^{12}$ Van Beuningen \& Koldeweij, Heilig en Profaan, 255 figs. 610-11; A.M. Koldeweij, 'Karel de Grote en de Borchgravinne van Vergi', in: Koldeweij \& Willemsen (eds.), Heilig en Profaan, 101-4. The fragmentarily preserved badge was found in Bruges some years ago, and is now in a private Dutch collection.
} 
Chatelaine of Vergi brooches prove that the story was not confined to elite circles but that it gained considerable popularity in the late fourteenth and early fifteenth centuries, although we do not know exactly how this happened. It is however just as likely that the story existed earlier in a more popular, widespread version which has not survived. In that case it would have evolved from that oral tradition into the more courtly, elitist version that was handed down in writing and later, in the sixteenth century, served as educational reading for the young and in schools. Should they really prove to be of popular origin, the two brooches are closer to the early, oral, narrative tradition; perhaps they are even the genuine source. ${ }^{13}$ All the other visual source material pertaining to the Chatelaine of Vergi story belongs to the culture of the upper social stratum, for instance the skillfully carved ivory caskets from France which date from the same period. A fourteenthcentury silver brooch on the cloak of a miraculous Holy Child in Switzerland might perhaps be seen as the costly, civilized counterpart of the vulgar Chatelaine of Vergi brooches which have been excavated: the courtly lady teaching tricks to her dog. ${ }^{\mathrm{I}}$

The motif of Aristotle and Phyllis comes from one of the best known and most widely disseminated stories of the late Middle Ages; the subject is also found throughout Western European art. Again, the visual source material is associated with elite culture and reflects the popularity of this ancient story in aristocratic and upper-class circles. ${ }^{15}$ However, from literary and other sources it is also clear that the amusing tale gradually percolated through to broader social strata, to ordinary folk. One of the female wiles enacted on a wagon in a Shrovetide procession at Metz in 1510 showed Aristotle mounted by Phyllis, ${ }^{16}$ and in 1511 the frolicking

\footnotetext{
${ }^{13}$ With acknowledgements to Prof. dr. W.P. Gerritsen, Utrecht, who discussed this issue with me and who will examine it in greater detail in the modern Dutch adaptation of the Borchgravinne van Vergi which he and Willem Wilminck are preparing. Regarding the aspect of school and children's readers see R.J. Ressoort, 'Een proper profitelijc boec', in: H. Bekkering \& P.J. Buinsters \& T. van Buul et al. (eds.), De hele Bibelbontse berg (Amsterdam 1989) 41-103; W.P. Gerritsen, 'De burggravin van Vergi uit het slijk gehaald', Nederlandse Letterkunde 2 (1997) 67-74.

${ }^{14}$ Johann Michael Fritz, Goldschmiedekunst der Gotik in Mitteleuropa (Munich 1982) 182, fig. VII, 331; Ronald W. Lightbown, Mediaeval European Jewellery (London 1992) 157 pl. 116 fig. 208.

${ }^{15}$ Cornelia Herrmann, Der "Gerittene Aristoteles" (Pfaffenweiler 1991).

${ }^{16}$ Herman Pleij, Het gilde van de blauwe schuit. Literatuur, volksfeest en burgermoraal in de late middeleeuwen (Amsterdam 1979) 197.
} 
couple appeared in the guise of snowmen in Brussels. ${ }^{17}$ From an item in the thirteenth-century sermon the traditional theme developed into a favourite courtly story and the subject of fifteenth and early sixteenth-century Shrovetide plays. ${ }^{18}$ As a scene in late medieval popular drama, "Aristotle ridden by Phyllis' is thus well documented. To my mind it is therefore more than likely that the most probably fifteenth-century pewter brooch in the form of the couple, found in Nieuwlande in Zeeland, was hawked in an environment of that kind (Fig. 7). A second, only slightly different but equally erotic, example was discovered in Ypres (Flanders); this badge predates 1383 , as is obvious from the archaeological context. ${ }^{19}$ Like the Chatelaine of Vergi brooch, the representation is highly erotic: none of the many hundreds of extant late medieval depictions of Aristotle being ridden shows the philosopher in such an explicit state of sexual arousal. This crude depiction of the legend surely appealed to a broad and unsophisticated public - exactly the kind of folk-drama audience we imagine. In one of the fifteenth-century Nuremberg Fastnachtspiele, for instance, relating how Aristotle was ridden by a female, we read that the text sought to convey the same effect. ${ }^{20}$ Addressing a King Soldan, Aristotle defends the ludicrous behaviour forced upon him by the monarch's consort. Soldan takes the wise philosopher's part, for he who 'sin ror niht auf tet stan' (i.e. does not have an erection) when tempted by a female was 'kein rechter man' (no proper man). ${ }^{21}$

At the end of such entertainments the audience were undoubtedly eager to buy their badges, just as they purchased devotionalia after reliquary processions or other religious spectacles.

As a visual source, and as an object of art- and culture-historical study, the late medieval, cheap and mass-produced badge is a much underrated but incredibly rich category. The enseignes belong to an imagery which was used to distinguish an individual in the late Middle Ages: individuals and

\footnotetext{
${ }^{17}$ Herman Pleij, De sneeuwpoppen van 1511. Stadscultuur in de late middeleeuwen (Amsterdam \& Louvain 1988) 86, 93, 267-8.

${ }^{18}$ Bernhard Sowinsky, 'Aristoteles als Liebhaber in den Deutschen Dichtungen des Spätmittelalters', Archiv für Kulturgeschichte 69 (1987) 315-29.

${ }^{19}$ Private collection, Ypres; h. 32 w. 21 mm. I am grateful to H.J.E. van Beuningen for documenting this badge.

${ }^{20}$ Sowinski, 'Aristoteles', 323-4; Herrmann, 'Der Gerittene Aristoteles', 62-3.

${ }^{21}$ Ain Spil von fürsten und herren $(151,20921)$, cited by Herrmann, 'Der Gerittene Aristoteles', 63.
} 
groups used, and still use, attributes and symbols for the purpose of presenting a certain image. That image confirms and/or enhances a person's social status, or the status he would like to have. The depicted subject was understood by everyone belonging to the group in which the wearer of that particular ornament moved, for only if the representation could be recognized and understood was it relevant and significative. This implies that the group of enseignes is a wonderful source, an indicator, of the dissemination of stories and knowledge, belief and superstition. However, it does not imply that all representations can be interpreted literally and with modern exactitude: even on an associative level, referring more or less accurately to, or reflected in, representations and texts as their point of departure, the badges had their special significance. Even if an inscription was misunderstood and incorrectly copied, even if letters were mangled beyond recognition, even if the details of representations faded or the representations themselves underwent crucial changes, the meaning and connotation certainly remained intact in a more general sense for both the wearer and the beholder.

The entire range of late medieval Western imagery is also found on enseignes. Generally speaking, it is based on three traditions: classicalsecular; biblical and Christian-religious; and thirdly - the trickiest to define - the tradition of popular culture, in which belief and superstition are most inextricably entangled. Even in the Middle Ages, which laid the foundations for the Western language of symbols that survives to this day, the three elements cannot be cleanly separated. Indeed, the congruence or overlapping of images and meanings is often seen to be essential (take, for instance, the both biblical and classical cornerstone of the Golden Fleece, a symbol adopted by the Burgundians, or Aristotle and Phyllis as one of the moralistic female wiles in the largely biblical series).

Hitherto, most of the research pertaining to such use of attributes and symbols has addressed Western monarchs, royal houses and state institutions, the nobility and elite culture. Investigation of insignia, the symbols and attributes of humbler dignitaries, of various governmental levels and of the citizenry has been conducted on a much smaller scale. Even less research has been devoted to the imagery used by larger population groups for their symbols and attributes, some of which - and this is certainly an important aspect - reflect those of higher social groups, others running parallel and either being 'original' or originating in completely different sources. 
We see, then, that late medieval and early modern insignia dating from the twelfth to the mid-sixteenth century take the form of costly unique pieces fashioned from precious metals, sometimes combined with other precious materials, and of badges, brooches and ornaments which were produced cheaply and in large quantities and distributed over the widest possible sections of the public.

The few secular pewter brooches examined in closer detail in this article belong to a category of cultural-historical material which as late medieval 'mass-produced merchandise' might be said to represent the fringe of medieval art; this involves a variety of aspects ranging from materials, workmanship and artistic quality to the subject matter of the image and the message. Closer examination of these mass-produced items will be innovative on various counts and is expected to yield surprising results which will necessitate an adjustment of the customary view of late medieval culture and will have consequences for earlier and later periods. I refer here to two more spectacular aspects:

1. The early mass production of such culturally valuable items as enseignes, significative ornaments, has powerful implications for the dissemination of images and ideas in the period in question: limited neither socially nor geographically, a phenomenon which is traditionally placed in the fifteenth century and later, i.e. linked with the advent of the wood and metal cut, promptly followed by printing. ${ }^{22}$

2. The interpretation and publication of a large group of ornaments with sexual subject matter of an amazing variety and degree of abstraction,

\footnotetext{
${ }^{22}$ It is interesting to note the direct and causal relationship between the two forms of culturally important mass production: Gutenberg, who developed movable print, had formerly been involved in the professional casting of pilgrim badges. Kurt Köster, 'Gutenbergs Aachener Heiltumspiegel', in: Das Werck der Bücher. Festschrift für Horst Kliemann (Freiburg i. Br. 1956) 284-301; Kurt Köster, 'Gutenbergs Strassburger Aachenspiegel-Unternehmen von 1438/1440', Gutenberg-Jahrbuch (1983) 22-24. Hans Belting, in his recently published monumental work Bild und Kult. Eine Geschichte des Bildes vor dem Zeitraum der Kunst (Munich 1990) 474-83, also assigns to 'Druckgraphik' the innovative role of the first mechanical image production, emphasizing the at first markedly elitist character (court, nobility, wealthy bourgeoisie) of these reproductive devices. This is cited in P.G.J. Post's 'Besprekingsartikel', 'Beeld en ritueel', Volkskundig Bulletin 17 (1991) 279-80. Elsewhere in his book, and only in passing, Belting assigns a comparable role to pilgrim badges, albeit not before the first quarter of the sixteenth century; Belting, Bild und Kult, 507-8.
} 
dating from the late thirteenth to the early fifteenth century, presents a virtually unknown facet of (popular) culture and calls for a new look at attitudes towards sexual matters, at least in the period in question. ${ }^{23}$

In this latter category, too, there is a remarkable overlapping of the aforementioned traditions: classical and secular themes which, when represented on cheap 'jewellery', take on a more pronounced erotic character than in any other context (for example the Chatelaine of Vergi and Aristotle and Phyllis brooches discussed above). More generally, this 'erotic' material will lead to a revision of our ideas about Christianity and 'paganism', or rather non-Christianity, in the civilized Western world; this visual culture seems to indicate that elements of popular beliefs presumed to have vanished for good in the eleventh and twelfth centuries under the influence of Christianity were still flourishing in the following centuries. It moreover seems essential to allot a specific place to the visual aspect, to symbol and attribute, in studying the magic and popular beliefs of the late Middle Ages and the Early Modern period, something which has received only extremely marginal consideration hitherto. ${ }^{24}$

Late medieval 'jewellery' - the perfect vehicle, then, for conveying meaning - can be a vital factor in answering a number of essential questions pertaining to the implications of visual historical material, to the language of images, to the functioning of the image and to dissemination in time and space of form, symbol and sign.

Virtually the only way to obtain that answer is to scrutinize material found in archaeological excavations. At a rough estimate some five thousand intact or fragmentary pewter badges dating from the late twelfth to the mid-sixteenth century have been found in the North and South Netherlands. Considerably smaller but still relevant quantities have been unearthed in other north-western European countries. Further visual source material (notably painted or drawn) cannot offer such a survey or comprehensive picture in view of its intrinsically elite character and the relatively late period in which it was made, i.e. the later fifteenth and sixteenth centuries.

${ }^{23}$ Compare, for instance, the pertinent observations in Michael Camille's authoritative The Gothic Idol. Ideology and Image-Making in Medieval Art (Cambridge 1989), esp. 87-101 and 322-4.

${ }^{24}$ See for instance Richard Kieckhefer, Magic in the Middle Ages (Cambridge 1989); Keith Thomas, Religion and the Decline of Magic (London 1971). 
Future research will have to address the various aspects of the enseigne in the late Middle Ages and early Renaissance by consulting a wide range of source material. The following itemized and of course interrelated themes will have to be considered:

- Individual interpretation and dating of enseignes.

- Examination of complexes of findings, the 'total picture' yielded by a location, a town, a region, correlated of course to the time factor.

- Geographical distribution: production centres and area of distribution. This can be defined with great accuracy in the case of pilgrim badges; pilgrim badges can probably serve as 'guide fossils' for related material.

- Unique and mass-produced pieces: on the one hand occasional, luxury enseignes, produced as one-offs or in very small series, and on the other hand badges made in large quantities for ordinary folk, and their interrelationship. Again, it is the pilgrim badges that supply clearly documented examples: precious unique pieces fashioned for the elite, and large series of mass-produced pieces for the common pilgrim (ranging from a few dozen a year to a peak in the fifteenth century, when tens of thousands of items were produced and sold every season).

- Subject and imagery are the same in both unique and mass-produced pieces, but material and workmanship differ. A significant circumstance in terms of cultural history is that in this manner the same imagery was accessible to, and employed by, people in all walks of life. For example, the gold or silver coin-brooch reached the masses in the form of its cheap pewter equivalent; the rich bought pilgrim badges made of precious metals, while cast pewter versions were sold to the poor pilgrim.

- This early mass production, known from the late twelfth century on and apparently peaking in the fourteenth and fifteenth centuries, has hitherto unacknowledged consequences for the geographical distribution of visual themes.

Written and visual source material, the latter in the form of the unearthed badges, are mutually complementary; the combination yields a well-nigh inexhaustible mine of cultural-historical information. There is a great diversity of themes to be analyzed, religious as well as secular and ranging from belief to superstition, from lofty to vulgar. Detailed scrutiny of this late medieval mass-produced item will produce results in a broader sense too. Perhaps a previously published article of mine may serve as an example; it examines the remarkable correspondence between the margin 
decoration of a Roman de la Rose manuscript and some of the erotic badges, ultimately defining the function and meaning of these badges not in more general and anthropological terms, but on the basis of a direct (art-)historical parallel. ${ }^{25}$

The objects provide material evidence of behavioural patterns which as such can only be reconstructed from a host of data: a pile of what seem to be mere curiosa or local snippets of information can turn out to be an entire building. The object can free the random written source from its isolation; conversely, the written source can do the same thing for the object discovered by chance. A report of the Holy Sacrament devotion at Boxtel, for example, gains a great deal more perspective when the different kinds of information are brought to bear on it: not long ago I identified for the first time two badges painted partly blood-red as evidence of devotional journeys undertaken from the find-spots, Sluis and Dordrecht, to Boxtel, a place of pilgrimage where the miracle of the Sacred Blood was celebrated. ${ }^{26}$ A painstakingly administered penance between 1452 and 1458 in the form of an expiatory pilgrimage from Lier tells almost the same story in a different way: ${ }^{27}$ 'i pelgrimagie ten heylegen bloede te Boxtel ende goede brieve daer af over brengen' (' 1 pilgrimage to the holy blood at Boxtel where the good letter is to be delivered'). This was duly accomplished, in view of the corollary 'satisfecit de peregrinacione'. The popular core of the miracle is represented on the badges: the fallen chalice and the ineradicable bloodstain on the altar cloth (Fig. 6).

A badge would illustrate the aspect with the greatest direct appeal to facilitate recognizability. This is certainly true of the religious material, but we should not assume that secular badges were any different. Indeed, the dramatic aspect could be taken to extremes, as is obvious within the context of this article in the cases of the Chatelaine of Vergi (Figs. 4 \& 5) and Aristotle and Phyllis (Fig. 7).

${ }^{25}$ A.M. Koldeweij, 'Erotische insignes en een Roman de la Rose-handschrift', in Van Beuningen \& Koldeweij, Heilig en Profaan, 110-14; A.M. Koldeweij, 'A Barefaced Roman de la Rose (Paris, B.N., ms. fr. 25526) and Some Late Medieval Mass-Produced Badges of a Sexual Nature', in: Maurits Smeyers (ed.), Flanders in a European Perspective. Manuscript Illumination around 1400 in Flanders and Abroad (Louvain, 1995) 499-516.

${ }^{26}$ Van Beuningen \& Koldeweij, Heilig en Profaan, 143 figs. 123, 124.

${ }^{27}$ E. van Cauwenbergh, Les pèlerinages expiatoires et judicaires dans le droit communal de la Belgique au Moyen-Age (Louvain 1922) 212. 


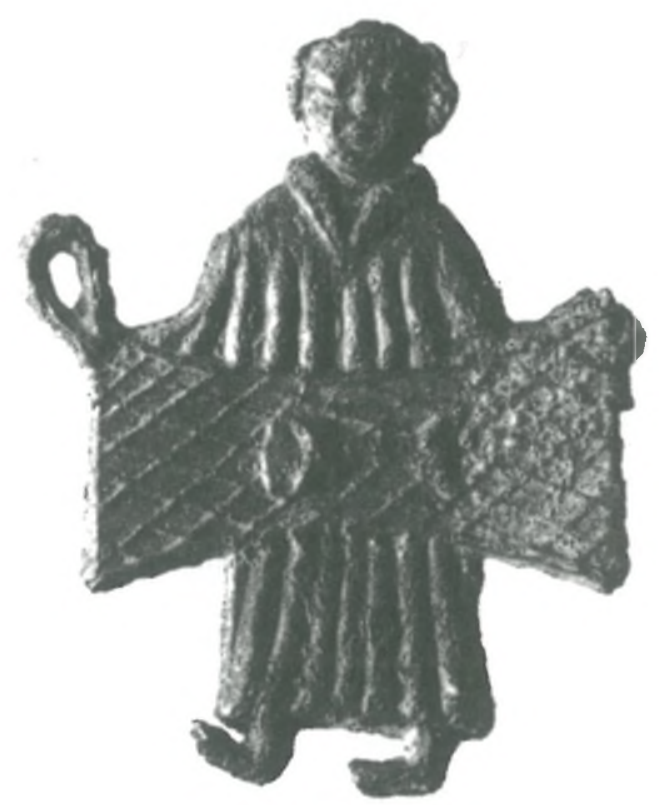

Figure 6. Badge in the form of a priest displaying the blood-stained altarcloth and the fallen chalice. Pilgrim badge from Boxtel (Neth.), lead-tin, $46 \times 38 \mathrm{~mm}$, c. 1350-1400, found in Sluis (Neth.). Coll. H.J.E. van Beuningen, Cothen (Neth.).

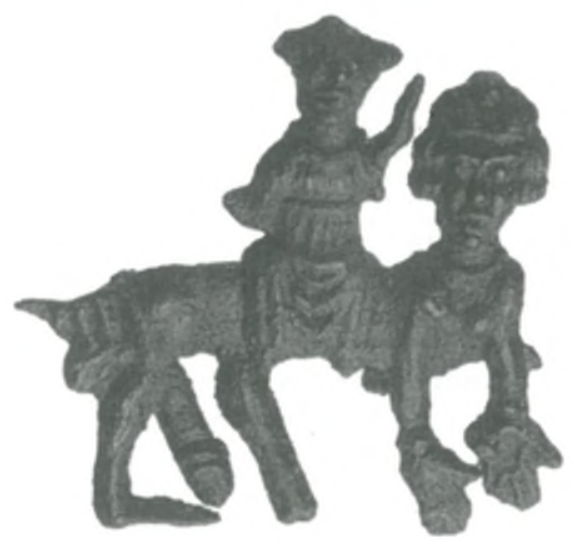

Figure 7. Badge in the form of Aristotle and Phyllis, lead-tin, $26 \times 28 \mathrm{~mm}$, c. 1375-1425, found in Nieuwlande (Neth.). Coll. H.J.E. van Beuningen, Cothen (Neth.). 
The pewter badge representing the mounted Aristotle was excavated in Nieuwlande on the island of Zuid Beveland, a village which was submerged in 1530-32. It probably dates from the latter half of the fifteenth century, but may be earlier. The find from Ypres is quite spectacular, for this badge is surely fourteenth-century. ${ }^{28}$ The story of Aristotle being made a fool of by Campaspe, Phyllis or another woman who rode on his back while he was on all fours, thereby arousing his passion, was, as we have already seen, very well known. It is one of several variants of an ancient oriental theme. In the Middle Ages the motif became attached to Aristotle, the wise philosopher who so foolishly indulged in such undignified behaviour. In both narrative and depicted form the story enjoyed great popularity from the mid-twelfth century up into the sixteenth, both as an isolated anecdote with a moral and as an illustration of various 'female wiles' ${ }^{29}$ To this day the pewter badges are extremely rare, but as representatives of large quantities of cast badges they indicate that the story was known in the Netherlands and to a wide public. Their overt sexuality is highly remarkable: this is the most erotic of all known representations of the climax of the story - Aristoteles Equitatus, the philosopher crawling on all fours with the charming temptress astride his back. Even when Phyllis and/or Aristotle are depicted quite naked, the male figure's state of arousal is never flaunted so ostentatiously as on this badge. The lewd representation suddenly links the popular, moralizing, 'classical' theme with the many overtly sexual badges, ${ }^{30}$ and contrasts sharply with the other, more elite and more 'civilized' depictions of the theme. Logically, then, this badge reflects the blatantly erotic tenor of folk drama on the theme of Aristotle hoist, as it were, with his own petard, and may even be regarded as a visual source for such plays.

Another extremely unusual badge, intriguing in the context of the popularization and dissemination of knowledge in the late Middle Ages, surfaced a few years ago during work on sewers in Zierikzee, Zeeland. Likewise unique of its kind to date, the relatively large badge represents the Wheel of Fortune (Fig. 8). ${ }^{31}$ Only part of the intricately cast, openwork

\footnotetext{
${ }^{28}$ Van Beuningen \& Koldeweij, Heilig en Profaan, 241 fig. 539.

${ }^{29}$ Herrmann, Der "Gerittene Aristoteles".

${ }^{30}$ The first comprehensive survey of this material, with references to older literature in the accompanying articles, is given in Van Beuningen \& Koldeweij, Heilig en Profaan.

${ }^{31}$ Van Beuningen \& Koldeweij, Heilig en Profaan, 323 fig. 1036.
} 


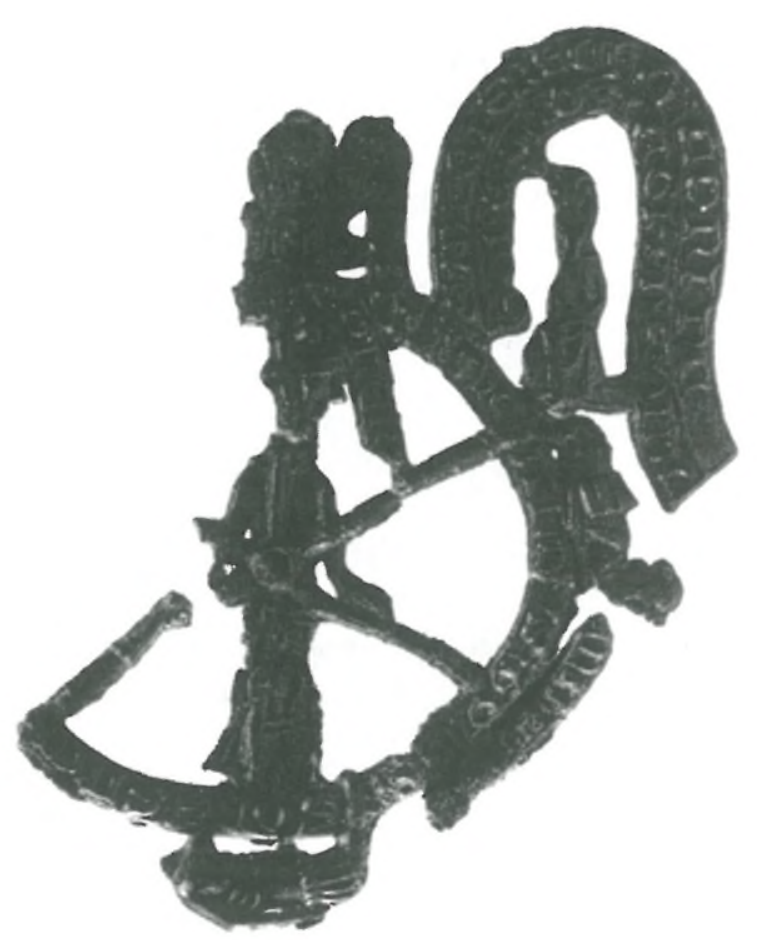

Figure 8. Badge representing Dame Fortune turning her wheel, lead-tin, $58 \times 41 \mathrm{~mm}, \mathrm{c}$. 1375-1425, found in Zierikzee (Neth.). Museum van Zierikzee, Zierikzee (Neth.).

pewter badge has survived. Even so, its meaning is patently clear: the central figure is Dame Fortune turning her wheel; the king at the top middle, marking the pinnacle of his power, is tumbling down the right-hand side of the wheel towards the nadir, presumably to scramble back up the missing left-hand rim. Here the theme, best known from Boethius, ${ }^{32}$ is captioned with a lengthy inscription in the popular idiom. It is tempting to regard such texts as Des Coninx Summe ${ }^{33}$ or medieval translations of

${ }^{32}$ Pierre Courcelle, La Consolation de philosophie dans la tradition littéraire (Paris 1967), ch. 3: Les images de Boèce et Fortune; Ehrengard Meyer-Landrut, Fortuna. Die Göttin des Glücks im Wandel der Zeiten (Berlin 1997).

${ }^{33}$ D.C. Tinbergen, Des Coninx Summe (Leiden 1907). 
Boethius $^{34}$ as the source, but attempts to identify the fragmentary text have failed as yet. To this day only one parallel has been found for a representation of Vrouwe Avontuere and her wheel with a Dutch caption. It is in the famous ms. Néerl. 1 in the Bibliothèque Nationale, Paris; Boethius's De Consolatione Philosophiae from the library of Louis of Gruuthuse of Bruges, made in Ghent in about 1490 (Fig. 9). ${ }^{35}$ A winged Fortune with her wheel appears in a vision to Boethius, who is flanked by a personification of Philosophy and two muses. The banderoles belonging to the tumbling and climbing figures read: 'Ic ben int sneven' ('I am tottering'), 'Ic ben int leste verdreven' ('I am abased'), 'Ic werde verheven' ('I am raised') and 'Ic sit in gl(or)ien verheve(n)' ('I am exalted to glory'). These words, much simpler than those on the badgefragment, derive directly from the fairly common corresponding Latin inscriptions ${ }^{36}$ 'regno', 'regnavi', '(sum) sine regno', and 'regnabo' ('I reign', 'I have reigned', 'I am without sovereignty', and 'I shall reign'), to be found, for example, on the interlaced banderoles in the miniature at the beginning of the manuscript of Martin le Franc, L'Estrif de Fortune et de Vertu (South Netherlands, third quarter of fifteenth century) in the Royal Library, Brussels. ${ }^{37}$

A mid-fourteenth-century copper die-piece in the British Museum since 1856 shows, among other motifs, the surviving half of a Wheel of Fortune. ${ }^{38}$ With this die, series of identical brooches could be cut from thin precious metal; the relief of Dame Fortune's wheel was a good $4 \mathrm{~cm}$ high. It follows the conventional arrangement, surmounted by the monarch who has managed to clamber up from the lowest point. The banderole belonging to the figure of the king beside the wheel is uncaptioned. The pewter fragment from Zierikzee is a cheap, cast version of the costly Wheel of Fortune brooches probably made with the English die-piece. It is likely to have been produced and sold in fairly large quantities, as were the Einblattholzschnitte which gained popularity in the fifteenth century and in

${ }^{34}$ J.M. Hoek, De middelnederlandse vertalingen van Boethius De Consolatione Philosphiae (Harderwijk 1943).

${ }^{35}$ Maximiliaan P.J. Martens, Lodewijk van Gruuthuse (Bruges 1992) 147 (fig.) 145.

${ }^{36}$ Courcelle, La Consolation.

${ }^{37}$ Georges Dogaer, Flemish Miniature Painting in the 15th and 16th Centuries (Amsterdam 1987), title-page ill. and 51-5.

${ }^{38}$ Nigel Ramsay, 'Multiple Die-Piece', in: Age of Chivalry. Art in Plantagenet England 1200-1400 (London 1987) (exhibition catalogue Royal Academy of Arts) 395-6 cat. 450. 


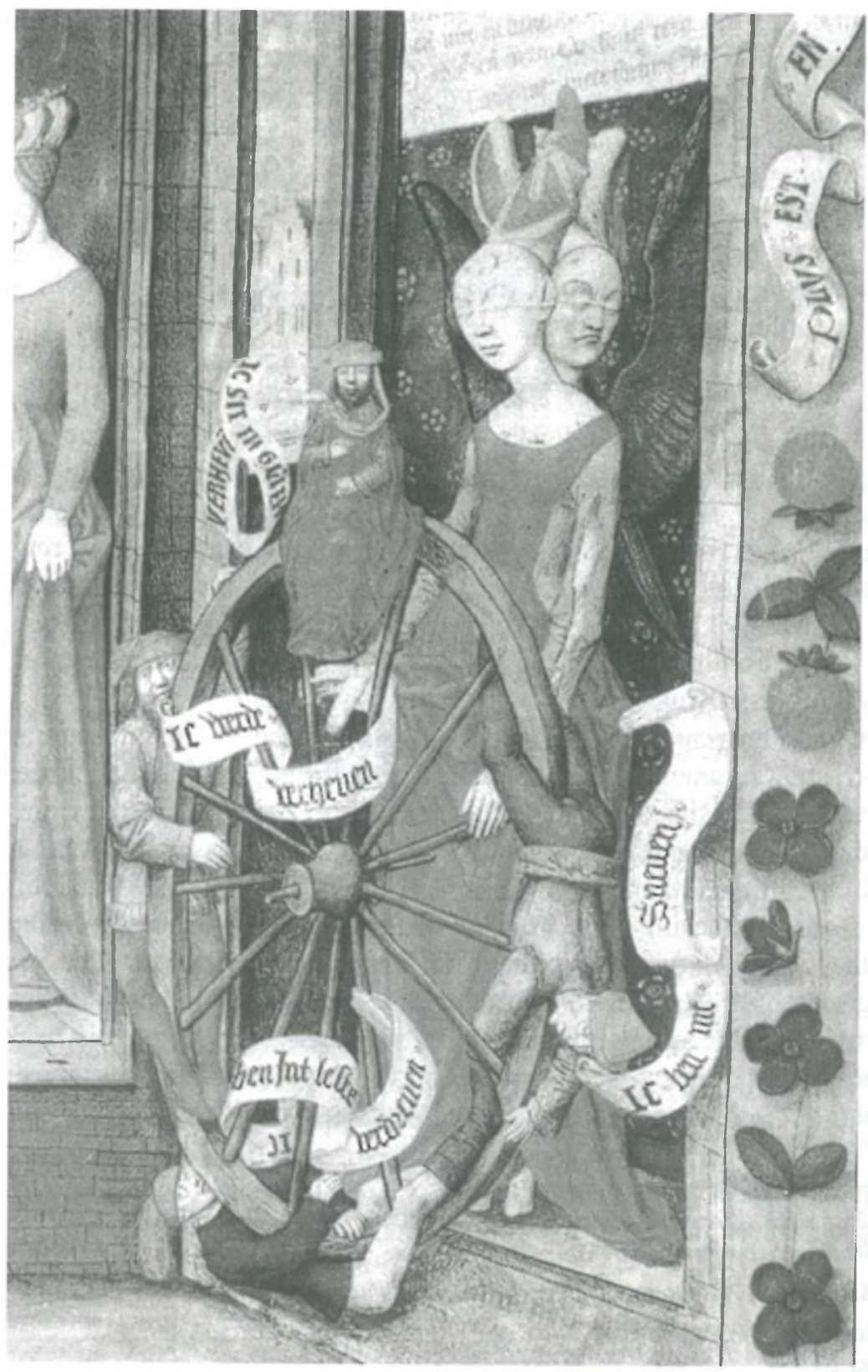

Figure 9. Dame Fortune turning her wheel, miniature (detail) in Boethius, De Consolatione Philosophiae, Ghent c. 1490. Bibliothèque Nationale, Paris, ms. Néerl. 1, f. 57v. 
my opinion supplanted the badges - the cast depictions. A Wheel of Fortune is found on a print of this type. ${ }^{39}$

Again, we can search for public spectacles which occasioned the sale of these 'mass-produced items', for events which made what was basically quite an intellectual theme accessible to a wider section of the population. A spectacular example is of course the huge Wheel of Fortune forming the rose window in the north transept of Basle Cathedral. The window swivelled in its oak frame; a sculpted Dame Fortune probably turned the wheel. ${ }^{40}$ To be mentioned in a Netherlandish context is Het radt van avontuyr documented before 1554, which was borne along in the Sacramental procession held at Maastricht, probably on a wagon; reports of the procession also mention scenes from the life of Christ, angels, saints and martyrs, Moresque dancers, giants and giantesses, and 'duvelen met hoeren capiteyn Lucifer' ('devils with their captain Lucifer'). ${ }^{41}$

And lastly, in exceptional cases a badge's cultural-historical story can be told even if the object itself has not been preserved. A curious report written some hundred and fifty years after the event mentions a plain pewter badge of the Virgin Mary which the devout Louis XI of France was wont to pin humbly to his hat. It all goes to show that the cheap, massproduced items should not be exclusively associated with the lower social stratum, and that its very 'worthlessness' could invest it with greater meaning for an upper-class wearer. The following observation about the collection of curiosa at Fontainebleau was penned in 1620:

${ }^{39}$ Blockbücher des Mittelalters (Mainz 1991) (exhibition catalogue Gutenberg-Museum) 191 cat. $48 \mathrm{~b}$.

${ }^{40}$ In 1885 the rose window was replaced by a sandstone copy. Fragments of the original oak wheel are kept in the Stadt- und Münstermuseum at Basle. Hans Reinhardt, Das Basler Münster. Die spätromanische Bauperiode vom Ende des XII. Jahrhunderts (Basle 1926) 37-40; Adolf Reinle, Kunstgeschichte der Schweiz I (Frauenfeld 1968) (= revised reprint of the first edition by Joseph Gantner, 1936) 383 (ill.), 393; Friedrich Kohler, 'Fensterrose', in: Reallexikon zur deutschen Kunstgeschichte 8 (Munich 1987) col. 70, 82, 123, 131; François Maurer-Kuhn, Das Münster von Basel, Schweizerische Kunstführer (Basle 1976) 22.

${ }^{41}$ H.P.H. Eversen, 'De Maastrichtse rederijkers-kamers. Eene bijdrage tot de Geschiedenis der Nederlandsche Letterkunde', Publications de la Société Historique et Archéologique dans le Duché de Limbourg VIII (1871), 329. Renate Kroos, Der Schrein des heiligen Servatius in Maastricht und die vier zugehörigen Reliquiare in Brüssel, Veröffentlich-ungen des Zentralinstituts für Kunstgeschichte in München (Munich 1985) 339. 
Du Cabinet de curiosités: 'J'ay mémoire, qu'il y a environ vingt ans, que l'on m'y montra une petite image de plomb représentant la Vierge, que l'on tenoit estre la mesme que Louis XI portoit ordinairement à son chapeau, de laquelle parle Philippe de Commines, au livre second de ses Mémoires, chapitre 8. Et de fait j'ay ouy dire à plusieurs anciens de ce lieu, qu'ils avoient appris que estoit la mesme: mais retournant voir ce cabinet depuis peu, ie ly ay cherché et ne l'ay pu trouver; ce qui me fait croire que comme elle estoit petite environ la longueur d'un doigt, elle peut estre égarée: elle estoit alors attachée au veloux de ces armoires. ${ }^{, 42}$

The chronicler Philippe de Commynes tells us more, however. ${ }^{43} \mathrm{He}$ describes the strikingly devout simplicity of King Louis, who wore a cheap lead badge on his hat and similar ones on his silk collar. In 1468, when he met the Spanish king, Enrico IV of Castile, in Bayonne, the Spaniards scoffed at his drab attire and the peculiar, shabby hat which sported a lead badge! No matter how devotional his motives, it was unseemly for a monarch to wear commonplace trinkets. Etiquette brooked no infringement: enseignes were quite literally signs — of social status too.

\footnotetext{
42 'On the cabinet of curiosities: I remember some twenty years ago being shown a small lead image of the Virgin which was said to be the one usually worn by Louis XI on his hat as reported by Philippe de Commines in chapter 8 of the second book of his Mémoires. And indeed, I have heard tell of several old people of this place who thought it was the selfsame one: but returning to view this cabinet a little while ago I searched for it but could not find it, which makes me suspect, it being about the length of a finger, that it might have been mislaid, for it used to be pinned on velvet in these cabinets.' Père Daniel, Trésor des Merveilles de Fontainebleau, 1620. Cited from Laborde, Glossaire, 262-3.

${ }^{43}$ Lightbown, Jewellery, 195.
} 